\title{
A Simple and Effective Recirculating Hatchery for Salmonids
}

\section{Buric $\mathbf{M}^{1 *}$, Bláhovec $\mathbf{J}^{2}$ and Kouril $\mathbf{J}$}

${ }^{1}$ Faculty of Fisheries and Protection of Waters, South Bohemian Research Center of Aquaculture and Biodiversity of Hydrocenoses, University of South Bohemia in Ceske Budejovice, Czech Republic

${ }^{2}$ Trout farm Mlýny, Vacov-Žár 25, CZ3873, Stachy, Czech Republic

\begin{abstract}
Research into the use of recirculating aquaculture systems (RAS) addresses the question of how to achieve profitable production while consistently recycling water and nutrients with minimal fresh water demand and waste production. The RAS facilities require an adequate supply of fingerlings, and a facility for fingerling production in conjunction with each RAS can prevent disease transfer and ensure quality and continuous production. The time, space, and financial investment can be eliminated by hatching (purchased disease free ova) and rearing of fingerlings every 2-3 months. The present study evaluated (water quality assessment, feed utilization, production cycle duration) a simple low cost recirculating hatchery for salmonids as a safe and continuous source of fingerlings for further rearing in RAS. The tested recirculating hatchery enabled low cost efficient production on a small scale (at least 5 production cycles per year, $>63000$ fingerlings per each cycle), low fresh water demand $\left(0.05 \mathrm{I}_{\mathrm{sec}} \mathrm{se}^{-1}\right)$ with maintaining good rearing conditions, and environmental and zoohygiene safety. Such simple facilities can support the sustainability of inland aquaculture and strengthen the effort to deliver quality products with minimal operational and environmental costs.
\end{abstract}

Keywords: Aquaculture; Sustainability; Environment; Fish; Water

\section{Introduction}

The expanding human population requires ever more increasing sources of quality food [1,2]. The importance of adequate nutrition is a factor predicting future preferred diet composition, and the role of fish is likely to increase in human diets [2-4]. The ongoing over-exploitation of natural fish resources has led to expanded development of marine and freshwater aquaculture in recent decades $[1,4,5]$. Aquaculture is currently the fastest growing food-production sector, accounting about $50 \%$ of the world's food fish [4]. Economic, environmental, and zoo hygienic concerns have led to increased efforts to maximize water reuse and waste management [6-9] and development of various types of Recirculating Aquaculture Systems (RAS). One of the most important freshwater species reared in RAS is rainbow trout Oncorhynchus mykiss $[10,11]$, having high culinary and nutritional value [12-14] obtainable by plant-based diets [15]. Annual worldwide production of rainbow trout reached more than 770 thousand tons in 2011, approximately $40 \%$ more than in 2003, with the prospect of further growth [16].

The expanding use of RAS for salmonid production has led to increased demand for quality fingerlings to stock such facilities. RAS, as a closed intensive system, requires pathogen-free fingerlings of stable quality several times per year $[8,17,18]$, and the need for new hatchery facilities can be assumed. The potential detrimental effects of fish farms on the environment $[19,20]$, especially with usual hatchery placement in upper stretches of streams, may be mitigated by RAS systems for hatching and rearing fingerlings, which can reduce fresh water demands as well as the amount of effluent water [21]

A facility for fingerling production in conjunction with the RAS will prevent disease transfer and ensure quality and continuous production [22]. Maintaining brood stock requires time, space, and specialized care at high costs, and purchase of certified disease free eyed eggs for hatching and rearing of fingerlings every 2-3 months is an economical alternative. The production approach must comply with safety, environmental, and economic criteria [7,23]. We developed a simple recirculating hatchery with low initial construction costs and low demands for energy and fresh water. The main goals of the study were to evaluate the usability, effectiveness, sustainability, environmental safety, and potential negative/positive impacts of an RAS hatchery and to calculate the overall annual production and the potential profitability. The particular objectives were to evaluate fish performance and challenges of RAS hatchery function and to monitor water quality during rearing.

\section{Material and Methods}

\section{Hatchery system}

The study was conducted in the southern Czech Republic $\left(49^{\circ} 6^{\prime} 35.2^{\prime \prime} \mathrm{N}, 13^{\circ} 45^{\prime} 10.2^{\prime \prime} \mathrm{E}\right)$ in the foothills of the Bohemian Forest, and area of moderate mid-European climate. The Recirculating Hatchery System (RHS) was developed to supply a local Danish model RAS and other small trout farmers [17]. The hatchery was established in 2008, and in 2011 was rebuilt to its current state and closely monitored between years 2011 and 2013. The overall power consumption of the RHS was $1.6 \mathrm{kWh}$. The overall fresh water demand of the RHS was approximately $0.051 \mathrm{sec}^{-1}$.

The RHS consisted of two separate recirculating systems housed in an area of $\sim 65 \mathrm{~m}^{2}$. The 'nursery' system (Figure 1A) was designed for egg incubation, hatching, and rearing through the switch to exogenous feeding to the weight of $0.4-0.5 \mathrm{~g}$. The system consisted of 12 incubation apparatuses $\left(\sim 0.02 \mathrm{~m}^{3}\right.$, with optional down welling/circular flow system); 8 trays $\left(\sim 0.16 \mathrm{~m}^{3}\right)$ for initial fry feeding and further rearing; one retention tank $\left(1 \mathrm{~m}^{3}\right)$; and one sedimentation tank $\left(1.2 \mathrm{~m}^{3}\right)$ equipped

${ }^{*}$ Corresponding author: Buric M, Faculty of Fisheries and Protection of Waters, South Bohemian Research Center of Aquaculture and Biodiversity of Hydrocenoses, University of South Bohemia in Ceske Budejovice, Czech Republic, Tel: +420 387774 601; E-mail: buric@frov.jcu.cz

Received September 05, 2014; Accepted September 25, 2014; Published October 05, 2014

Citation: Buric M, Bláhovec J, Kouril J (2014) A Simple and Effective Recirculating Hatchery for Salmonids. J Aquac Res Development 5: 271. doi:10.4172/21559546.1000271

Copyright: (C) 2014 Buric M, et al. This is an open-access article distributed unde the terms of the Creative Commons Attribution License, which permits unrestricted use, distribution, and reproduction in any medium, provided the original author and source are credited. 

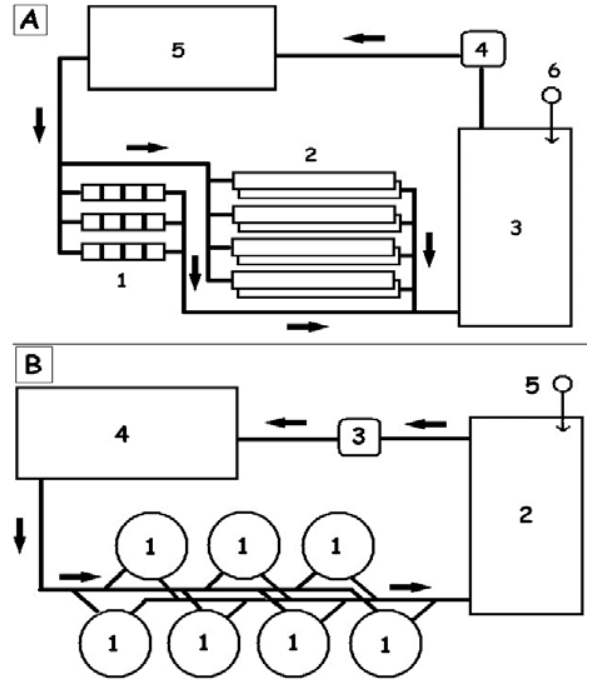

Figure 1: Schematic drawing of recirculation hatchery system: A - The nursery system: 1- Egg incubation unit, 2- Trays for initial feeding, 3- Sedimentation tank, 4- Pump, 5- Retention tank, 6- Fresh water inlet. B - The rearing system: 1- Circular tanks, 2- Bio filtration/sedimentation tank, 3- Pump, 4- Retention tank, 5- Fresh water inlet. Green lines represent distribution of water. Violet lines represent effluent water from rearing tanks.

with two bio-filtration units, Bioblocs (EXPO-NET A/S, Denmark), and a circulation pump (power consumption $0.55 \mathrm{kWh}$, Calpeda S.P.A., Italy). The total water volume was $\sim 3.8 \mathrm{~m}^{3}$, excluding piping. The fresh water demand of the nursery system for compensation of evaporation and losses incurred with tanks cleaning was $\sim 0.01 \mathrm{lsec}^{-1}$.

The 'rearing' system (Figure 1B), for rearing of fish from 0.4-0.5 g to $2.0 \mathrm{~g}$, consisted of seven circular tanks $\left(\sim 0.7 \mathrm{~m}^{3}\right)$; one biofiltration/ sedimentation unit $\left(\sim 2.2 \mathrm{~m}^{3}\right)$ equipped with 12 bioblocs; one retention tank $\left(\sim 3.5 \mathrm{~m}^{3}\right)$; and a circulation pump (power consumption 0.75 $\mathrm{kWh}$, Wilo SE, Germany). The total water volume was $\sim 10.6 \mathrm{~m}^{3}$, excluding piping. The fresh water demand for the rearing system, for compensation of evaporation and losses incurred with tanks cleaning, was $\sim 0.041 \mathrm{sec}^{-1}$.

\section{Physical and chemical conditions}

In 2011-2013, water samples from the RHS were collected biweekly at the tank outlets and analyzed in an accredited laboratory (Bioanalytika CZ, s.r.o., testing laboratory no. 1012) for level of ammonia $\left(\mathrm{NH}_{4}^{+}\right)$, nitrite $\left(\mathrm{NO}_{2}^{-}\right)$and nitrate $\left(\mathrm{NO}_{3}^{-}\right)$concentration, biological oxygen demand (BOD), chemical oxygen demand $\left(\mathrm{COD}_{\mathrm{Mn}}\right)$, alkalinity (acid-neutralization capacity), chloride concentration $\left(\mathrm{Cl}^{-}\right)$, and suspended solids. Oxygen saturation level (oximeter Oxi 3205 with CellOx 325, WTW Gmbh, Weilheim, Germany), $\mathrm{pH}$ (pH meter $\mathrm{pH}$ 330i with SenTix 41, WTW Gmbh, Weilheim, Germany), and water temperature (KM12 digital thermometer, Comark Instruments, Great Britain) were monitored daily.

\section{Animals and rearing conditions}

All-female populations of rainbow trout were used for RHS testing. Eyed eggs (80,000 per production cycle) were delivered from certified disease-free farms (Troutex ApS, Denmark) and placed in incubation units for hatching and approximately the first three days of free-living fry. Dead eggs were removed daily. During the hatching period, dead specimens and egg shells were removed regularly. The hatching period was characterized by foaming of water due to increased concentration of enzymes that soften the egg shells [24].

Approximately 3 days post-hatching, larvae were moved to trays where, after absorption of the majority of yolk, feeding (Inicio Plus G, Biomar A/S, Denmark) of the freely floating fry was initiated. During the initial feeing period the fry were fed in excess to trigger foraging activity. After a few days feeding was adjusted to ad libitum. Trays were cleaned regularly, usually once or twice daily, to remove faeces, uneaten feed, and dead or malformed specimens.

Fish fry were moved to the rearing system upon reaching weight of $0.45-0.50 \mathrm{~g}$. During the rearing period, fish were fed amounts ranging from $2.5-5.5 \%$ of fish biomass, according to water temperature, fish size, and appetite. Circular tanks were cleaned regularly to remove faeces and dead specimens. The biofiltration/sedimentation tanks were cleaned (sludge removal and cleaning of Bioblocs) on alternate days. The water flow in circular tanks was regulated by ball valves according to the size of fish and biomass. Natrium chloride was applied to maintain chloride $(\mathrm{Cl})$ content at $\sim 100 \mathrm{mgl}^{-1}$ to prevent a sudden increase in nitrite levels. After each production cycle, the nursery and rearing systems were cleaned, filled with fresh water, and disinfected by peracetic acid (PAA)

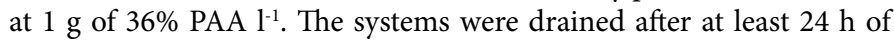
operation with disinfecting medium.

\section{Fish growth and feed conversion}

Eleven production cycles were carried out. A production cycle covered the time period from egg stocking in the RHC to individual fish weight of $2 \mathrm{~g}$ (total length 55-65 mm). Fish were weighed bi-weekly during each production cycle to the nearest $0.01 \mathrm{~g}$ using an electronic balance (Kern \& Sohn GmbH, Balingen, Germany). The first weighing was carried out when fish began exogenous feeding and continued until they reached $2 \mathrm{~g}$ and were transferred to the RAS. Daily mortality was recorded. The amount of feed offered per day was recorded. The feed conversion ratio (FCR) was calculated as

$\mathrm{FCR}=\mathrm{w}_{\mathrm{k}} / \mathrm{w}_{\mathrm{p}}$

where $\mathrm{w}_{\mathrm{k}}=$ amount of feed $(\mathrm{kg})$ and $\mathrm{w}_{\mathrm{p}}=$ obtained weight increment (kg) [25].

\section{Data analysis}

Data were analysed using Statistica 9.0 (StatSoft, Inc.). Results were examined for normal distribution (Kolmogorov-Smirnov test) and homoscedasticity (Levene test). One-way ANOVA with Tukey's post hoc test was used to compare growth and feed conversion ratio. The null hypothesis was rejected at $\alpha=0.05$. Data are presented as mean \pm standard deviation.

\section{Results}

\section{Physical and chemical conditions}

Oxygen saturation during the monitored period was consistently $>85 \%$ and $>75 \%$ saturation at system inlet and outlet, respectively. Water temperature ranged from $9.1-13.9^{\circ} \mathrm{C}$ throughout the study with a maximum day change of $0.4^{\circ} \mathrm{C}$. $\mathrm{pH}$ values were 7.1-7.7 throughout the study. The biofilter function was adequate for fish biomass and the amount of daily feed, with almost optimal ammonia and nitrite content and proportionally increasing nitrate content. Only in the final phase of the production cycle, when biomass in the RHS reached maximum values of 170-200 kg, were higher values of ammonia (to $2.3 \mathrm{mg} \mathrm{l}^{-1} \mathrm{NH}_{4}^{+}$) and nitrite (to $4.9 \mathrm{mg} \mathrm{l}^{-1} \mathrm{NO}_{2}^{-}$) observed. However, due to near neutral $\mathrm{pH}$ and chloride content of approximately $100 \mathrm{mg} \mathrm{l}^{-1}$, the ammonia and 
Citation: Buric M, Bláhovec J, Kouril J (2014) A Simple and Effective Recirculating Hatchery for Salmonids. J Aquac Res Development 5: 271. doi:10.4172/2155-9546.1000271

Page 3 of 5

nitrite levels did not affect fish health. The level of organic compounds in water was low during the production cycle, reaching maximum BOD and $\mathrm{COD}_{\mathrm{Mn}}$ values of 2.5 and $4.1 \mathrm{mg} \mathrm{O}_{2} \mathrm{l}^{-1}$, respectively. The acidneutralizing capacity was optimal at 1-2 $\mathrm{mmol} \mathrm{l}^{-1}$. Detailed data from monitoring of collected water samples are shown in Table 1.

\section{Production cycle, fish growth and FCR}

The production period was consistently shorter than 3 months,

\begin{tabular}{|c|c|c|c|c|c|}
\hline Parameter & $\mathbf{n}$ & mean & STD & Min & Max \\
\hline Biomass $(\mathrm{kg})$ & 54 & 104.9 & 63.0 & 39.7 & 202.3 \\
\hline Water temperature $\left(^{\circ} \mathrm{C}\right)$ & 681 & 11.0 & 1.3 & 9.1 & 13.9 \\
\hline $\mathrm{pH}$ & 54 & 7.3 & 0.2 & 7.1 & 7.7 \\
\hline Total ammonia $\left(\mathrm{mg} \mathrm{l}^{-1}\right)$ & 54 & 0.9 & 0.6 & 0.2 & 2.3 \\
\hline Nitrite $\left(\mathrm{mg} \mathrm{l}^{-1}\right)$ & 54 & 0.8 & 0.7 & 0.1 & 4.9 \\
\hline Nitrate $\left(\mathrm{mg} \mathrm{l}^{-1}\right)$ & 54 & 47.6 & 33.4 & 11.0 & 96.3 \\
\hline Biological oxygen demand $\left(\mathrm{mg} \mathrm{l}^{-1}\right)$ & 54 & 1.4 & 0.5 & 1.0 & 2.5 \\
\hline Chemical oxygen demand $\left(\mathrm{mg} \mathrm{l}^{-1}\right)$ & 54 & 2.6 & 1.1 & 1.0 & 4.1 \\
\hline Suspended solids $\left(\mathrm{mg} \mathrm{l}^{-1}\right)$ & 54 & 3.3 & 1.5 & 2.0 & 5.0 \\
\hline Chlorides $\left(\mathrm{mg} \mathrm{l}^{-1}\right)$ & 54 & 94.1 & 37.58 & 43.71 & 130.96 \\
\hline Phosphorus $\left(\mathrm{mg} \mathrm{l}^{-1}\right)$ & 54 & 0.8 & 0.7 & 0.1 & 1.5 \\
\hline Alkalinity $\left(\mathrm{mmol} \mathrm{I}^{-1}\right)$ & 54 & 1.8 & 0.3 & 1.3 & 2.1 \\
\hline
\end{tabular}

Table 1: Summary of bi-weekly water quality assessments, measured during 11 production cycles of at least 2 months. Data are presented as mean \pm standard deviation and minimum and maximum values.

\begin{tabular}{|c|c|c|c|c|}
\hline Period & Duration & & Losses & \multirow{2}{*}{$\mathbf{n}$} \\
\hline Hatching period & days & $\%$ & $\%$ & \\
\hline Initial feeding period & $16.4 \pm 2.2^{\mathrm{b}}$ & $20.6 \pm 2.8^{\mathrm{b}}$ & $7.8 \pm 3.8^{\mathrm{b}}$ & 11 \\
\hline Rearing period & $29.3 \pm 4.3^{\mathrm{a}}$ & $36.8 \pm 5.4^{\mathrm{a}}$ & $10.7 \pm 3.5^{\mathrm{a}}$ & 11 \\
\hline Production cycle & $79.6 \pm 4.2^{\mathrm{a}}$ & $42.6 \pm 4.0^{\mathrm{a}}$ & $2.6 \pm 0.8^{\mathrm{c}}$ & 11 \\
\hline
\end{tabular}

Table 2: The average duration of each period of production cycle (days, \%), average losses during each period (\%), and the number of observed production cycles ( $n)$. Data are presented as mean \pm STD. Different alphabetic superscripts in the same column indicate significant differences at $\alpha=0.05$ (ANOVA, Tukey's post hoc test)

\begin{tabular}{|c|c|c|c|}
\hline Period & & \multicolumn{2}{|c|}{ FCR } \\
\hline & $\mathrm{n}$ & period & average \\
\hline Initial feeding period & 28 & $0.55 \pm 0.05^{\mathrm{b}}$ & \multirow{2}{*}{$0.66 \pm 0.09$} \\
\hline Rearing period & 33 & $0.71 \pm 0.07^{\mathrm{a}}$ & \\
\hline
\end{tabular}

Table 3: The average feed conversion ratio (FCR) in the initial feeding period and rearing period. Data are presented as mean \pm STD. Different alphabetic superscripts in the same column indicate significant differences at $\alpha=0.05$ (t-test). with the hatching period accounting for $20 \%$ and each of the further two periods about $40 \%$ of the time. The highest losses were observed during the initial feeding period and included mortalities as well as serious body malformations (Table 2). During each production cycle, high growth and low FCR was observed in both the initial feeding and the rearing period. FCR was lower in the initial feeding period (Table $3)$.

\section{Total yield per year}

From 2011 through 2013, 11 controlled production cycles produced 694,000 fingerlings $(1426 \mathrm{~kg}$ ). At least 4 production cycles were possible annually including time for cleaning and preparation of both RHS systems. The parallel use of the systems enables completion of at least 5 cycles per year (Table 4): Incubation of eyed ova, hatching, and the initial feeding period can be carried out concurrently during the final 20-25 days of the rearing period of the previous production cycle.

\section{Discussion}

The present study evaluated a recirculating hatchery system developed for supplying a trout farm and other small local farms. The development was focused on simplicity and effectiveness of production units and economic sustainability in the view of current and future requirements for environmental sustainability $[3,26]$. The RHS was developed as a simple facility without special structures or technologies, potentially enabling its use for large producers as well as smaller operations.

Evaluation of the RHS assessed usability and effectiveness (fish performance, possibilities and challenges in RHS function, and water quality), environmental sustainability (environmental safety, potential negative/positive impacts), and economic sustainability (production per year and the potential profitability).

The basic parameter affecting the usability and effectiveness of recirculating aquaculture systems is the fluctuation in nitrogen compound levels relative to fish biomass and the amount of feed supplied $[27,28]$. This parameter must be associated with a satisfactory feed conversion ratio and fish welfare $[29,30]$. The data obtained from water quality monitoring confirmed adequate biofilter function indicated by increase in non-toxic nitrates, low levels of ammonia and nitrite, stable $\mathrm{pH}$, and low level of organic load (Table 1) [28,31]. Manual feeding at short intervals and pathogen free fresh water intake provided rearing conditions with no negative impact on fish health and welfare [30]. Conditions resulted in rapid growth and low FCR, not only with

\begin{tabular}{|c|c|c|c|c|c|c|c|c|c|}
\hline & \multirow[b]{2}{*}{ days per $\mathrm{PC}$} & \multicolumn{2}{|c|}{ Power consumption } & \multicolumn{2}{|c|}{ Fresh water demand } & \multicolumn{2}{|c|}{ Personnel costs } & \multicolumn{2}{|c|}{ Production per one PC } \\
\hline & & $\begin{array}{l}\text { per day } \\
(\mathrm{kW})\end{array}$ & total per PC $(\mathrm{kW})$ & per day $\left(m^{3}\right)$ & $\begin{array}{c}\text { total per PC } \\
\left(\mathrm{m}^{3}\right)\end{array}$ & $\begin{array}{l}\text { per day } \\
\text { (hours) }\end{array}$ & $\begin{array}{l}\text { total per PC } \\
\text { (hours) }\end{array}$ & pcs & $\mathrm{kg}$ \\
\hline Nursing system & 46 & 20.9 & 960.5 & 0.86 & $39.70+3.90^{*}$ & $<4$ & $<184$ & $x$ & $x$ \\
\hline Rearing system & 34 & 25.7 & 873.1 & 3.46 & $117.64+11.00^{*}$ & $<3$ & $<102$ & $x$ & $x$ \\
\hline \multirow[t]{3}{*}{ Production cycle } & 80 & $\mathrm{x}$ & 1833.6 & 4.32 & $157.34+14.90^{*}$ & $x$ & $<286$ & 63200 & 127 \\
\hline & & \multirow{2}{*}{ Days } & \multirow{2}{*}{$\begin{array}{c}\text { Power } \\
\text { consumption (kW) }\end{array}$} & \multirow{2}{*}{$\begin{array}{c}\text { Water demand } \\
\qquad\left(\mathrm{m}^{3}\right)\end{array}$} & \multirow{2}{*}{$\begin{array}{l}\text { Personnel costs } \\
\text { (hours) }\end{array}$} & \multirow{2}{*}{$\begin{array}{c}\text { Total costs } \\
(\$)^{* *}\end{array}$} & \multicolumn{2}{|c|}{ Total production } & \multirow{2}{*}{$\begin{array}{l}\text { Net profit pe } \\
\text { year }(\$)^{\star *}\end{array}$} \\
\hline & & & & & & & (pcs) & $(\$)^{* *}$ & \\
\hline \multicolumn{10}{|c|}{ Four PC per year } \\
\hline & & 336 & 7334.4 & 688.4 & $<1280$ & $<22240$ & 252800 & 50560 & 28320 \\
\hline \multicolumn{10}{|c|}{ Five PC per year } \\
\hline & & 345 & 9168.0 & 860.5 & $<1725$ & $<27810$ & 316000 & 63200 & 35390 \\
\hline
\end{tabular}

Table 4: The summary table for the recirculation hatchery system for one production cycle (PC) including power consumption $(\mathrm{kW})$, fresh water demand ( $\left.\mathrm{m}^{3}\right)$, personne costs (hours), and production (pcs, $\mathrm{kg}$ ), and the summary table for four and five production cycles per year including calculation of total electricity, water, and personnel demands, total costs, total production, and net profit per year.

*Initial water volume necessary for filling all tanks.

${ }^{\star *}$ Converted from real fingerling prices and real costs of eyed ova, personnel, electricity, feed, and other costs of the company at the study site. 
Citation: Buric M, Bláhovec J, Kouril J (2014) A Simple and Effective Recirculating Hatchery for Salmonids. J Aquac Res Development 5: 271. doi:10.4172/2155-9546.1000271

a daily feed ration of approximately $5 \%$ of fish biomass, but during the initial feeding period when feed was supplied in excess.

The positive results obtained in a simple recirculating system call into question the reported need to use additional technologies for hatcheries such as UV treatment, ozone application, microsieve filtration, oxygenation, and aeration [32,33]. The RHS was fully functional without such treatments, thus is more efficient with respect to initial investment as well as operating costs. Nevertheless, potential use of additional technologies in enhance the RHS should be discussed. Added aeration and oxygenation may increase the capacity of RHS, but benefits such as increased production and increased biofiltration rate [34] are cancelled out by increased operating costs. Oxygen level and biofiltration efficacy were found to be sufficient in the current study. The same situation arises when the benefits and cost are compared for technologies, such as ozone treatment [32,35] and UV irradiation [33]. Elimination of these treatments requires adherence to strict zoohygiene principles, including purchase of eyed ova only from certified diseasefree providers. A possible option could be the addition of filtration, such as a simple microsieve filter or incorporation of small constructed wetland $[36,37]$ to the system to enable increase in the daily amount of feed without the need of extra power [37].

The RHS, as a simple unit for fingerling production can provide small farms with overall annual production of 150-300 tons with the possibility to sell a substantial portion of fingerling production to other farmers, with minimal fresh water demand and low operating costs. The use of a RHS may allow small producers to be independent of fingerling suppliers with effective, zoohygienic, and environmentally safe production. Compared to traditional salmonid hatcheries, often located on upper stretches of streams with possible negative impact on local oligotrophic ecosystems [20,38], RHSs can be established essentially anywhere, because of low fresh water demand. In recirculating hatcheries, the amount of waste water is substantially lower and more concentrated, which allows its collection, sedimentation, and potential use as fertilizer or its treatment through an constructed wetland to prevent the trophic changes to ecosystems $[9,17,19,39]$. The low energy demand has environmental as well as economic benefits.

The RHS could be a safe means of fingerling production throughout the year with positive economic and environmental benefits. The possibility of incorporating additional technologies, the effects of economic and environmental issues, as well as the use of different fish in RHS should be targets of future research.

\section{Acknowledgement}

The study was supported by the project CENAKVANo. CZ.1.05/2.1.00/01.0024, by the project LO1205 with financial support from the MEYS of the Czech Republic under the NPU I program, and by the Ministry of Agriculture of the Czech Republic (project No. NAZV QJ1210013). We also deeply appreciate the assistance of the Lucidus Consultancy for the language editing of this manuscript.

\section{References}

1. Food and Agriculture Organization of United Nations (2013) FAO yearbook, Fishery and Aquaculture Statistics 2011 1-105.

2. National Inteligence Council (2012) Global Trends 2030: Alternative worlds. A publication of National Intelligence council, USA 1-160.

3. Cole DW, Cole R, Gaydos SJ, Gray J, Hyland G, et al. (2009) Aquaculture: Environmental, toxicological, and health issues. Int $\mathrm{J}$ Hyg Environ Health 212: 369-377.

4. Food and Agriculture Organization of United Nations (2014) The State of World Fisheries and Aquaculture, Opportunities and challenges 1-243.

5. Naylor RL, Goldburg RJ, Primavera JH, Kautsky N, Beveridge MCM, et al. (2000) Effect of aquaculture on world fish supplies. Nature 405: 1017-1024.
6. Ayer NW, Tyedmers PH (2009) Assessing alternative aquaculture technologies: life cycle assessment of salmonid culture systems in Canada. J Cleaner Prod 17: 362-373.

7. Martins CIM, Eding EH, Verdegem MCJ, Heinsbroek LTN, Schneider O, et al. (2010) New developments in recirculating aquaculture systems in Europe: A perspective on environmental sustainability. Aquacult Eng 43: 83-93.

8. Midilli A, Kucuk H, Dincer I (2012) Sustainability aspects of a recirculating aquaculture system. Environ Prog Sustain 31: 604-611.

9. Van Rijn J (2013) Waste treatment in recirculating aquaculture systems. Aquacult Eng 53: 49-56.

10. Jokumsen A, Pedersen PB, Dalsgaard AJT, Lund I, Paulsen H, et al. (2009) New methods in trout farming to reduce the farm effluents - Case study in Denmark. Handbook for sustainable Aquaculture.

11. Roque d'Orbcastel E, Blancheton JP, Aubin J (2009) Towards environmentally sustainable aquaculture: comparison between two trout farming systems using Life Cycle Assessment. Aquacult Eng 40: 113-119.

12. Blanchet C, Lucas M, Julien P, Morin R, Gingras S, Dewailly É (2005) Fatty acid composition of wild and farmend Atlantic salmon (Salmo salar) and rainbow trout (Oncorhynchus mykiss). Lipids 40: 529-531.

13. Dewailly É, Ayotte P, Lucas M, Blanchet C (2007) Risk and benefits from consuming salmon and trout: A Canadian perspective. Food Chem Toxicol 45: 1345-1349.

14. Wall R, Ross RP, Fitzerald GF, Stanton C (2010) Fatty acids from fish: the antiinflammatory potential of long-chain omega-3 fatty acids. Nutr Rev 68: 280-289.

15. Turchini GM, Francis DS, Keast RSJ, Sinclair AJ (2011) Transforming salmonid aquaculture from a consumer to a producer of longchain omega-3 fatty acids. Food Chem 124: 609-614.

16. Food and Agriculture Organization of United Nations (2012) The State of World Fisheries and Aquaculture 1-209.

17. Buřič $\mathrm{M}$, Bláhovec $\mathrm{J}$, Kouřil $\mathrm{J}$ (in press) Feasibility of open recirculating system in temperate climate - a case study. Aquac Res (doi:10.1111/are.12572).

18. Jokumsen A, Svendsen LM (2010) Farming of freshwater rainbow trout in Denmark. DTU Aqua, National Institute of Aquatic Resources, Denmark 48.

19. Wang X, Olsen LM, Reitan KI, Olsen $Y(2012)$ Discharge of nutrient wastes from salmon farms: environmental effects, and potential for integrated multitrophic aquaculture. Aquac Environ Interact 2: 267-283.

20. Webb JA (2012) Effects of trout farms on stream macroinvertebrates: linking farm-scale disturbance to ecological impact. Aquac Environ Interact 3: 23-32.

21. Wilfart A, Prudhomme J, Blancheton JP, Aubin J (2013) LCA and energy accounting of aquaculture systems: Towards ecological intensification. J Environ Manage 121: 96-109.

22. Salama NKG, Murray AG (2011) Farm size as a factor in hydrodynamic transmission of pathogens in aquaculture fish production. Aquac Environ Interact 2: 61-74.

23. Rawlinson $P$, Forster $A$ (2001) The economics of recirculation aquaculture Microbehaviour and Macroresults: Proceedings of the Tenth Biennial Conference of the International Institute of Fisheries Economics and Trade. Oregon State University, Corvallis, USA 14.

24. Gray J (1928) The growth of fish. The effect of temperature on the development of the eggs of Salmo fario. Br J Exp Biol 6: 125-130.

25. EIFAC (1980) Report of the EIFAC/IUNS and ICES working group on standardization of methodology in fish nutrition research, EIFAC Technical Paper - EIFAC/T36.

26. Boeing WJ (2013) Aquaculture: an Ecologist's Perspective. J Fisheries Livest Prod 1: 2.

27. Van Rijn J (1996) The potential for integrated biological treatment systems in recirculating fish culture -A review. Aquaculture 139: 181-201.

28. Suhr KI, Pederesen PB (2010) Nitrification in moving bed and fixed bed biofilters treating effluent water from a large commercial outdoor rainbow trout RAS. Aquacult Eng 42: 31-37.

29. Ross RM, Watten BJ, Krise WF, DiLauro MN (1996) Influence of tank design and hydraulic loading on the behavior, growth, and metabolism of rainbow trout (Oncorhynchus mykiss). Aquacult Eng 14: 29-47. 
Citation: Buric M, Bláhovec J, Kouril J (2014) A Simple and Effective Recirculating Hatchery for Salmonids. J Aquac Res Development 5: 271. doi:10.4172/2155-9546.1000271

Page 5 of 5

30. Rasmussen RS, Larsen FH, Jensen S (2007) Fin condition and growth among rainbow trout reared at different sizes, densities and feeding frequencies in high-temperature re-circulated water. Aquacult Int 15: 97-107.

31. Davidson J, Good C, Welsh C, Summerfelt ST (2014) Comparing the effects of high vs. low nitrate on the health, performance, and welfare of juvenile rainbow trout Oncorhynchus mykiss within water recirculating aquaculture systems. Aquacult Eng 59: 30-40.

32. Summerfelt ST, Hankins JA, Weber AL, Durant MD (1997) Ozonation of a recirculating rainbow trout culture system II. Effects on microscreen filtration and water quality. Aquaculture 158: 57-67.

33. Sharrer MJ, Summerfelt ST, Bullock GL, Gleason LE, Taeuber J (2005) Inactivation of bacteria using ultraviolet irradiation in a recirculating salmonid culture system. Aquacul Eng 33: 135-149.

34. Clark ML (2003) Comparison of water quality, rainbow trout production, and economics in oxygenated and aerated raceways. Master thesis, Virginia Polytechnic Institute and State University, Blacksburg, Virginia, 73.
35. Davidson J, Good C, Welsh C, Summerfelt S (2011) The effects of ozone and water exchange rates on water quality and rainbow trout Oncorhynchus mykiss performance in replicated recirculating systems. Aquacult Eng 44: 80-96.

36. Chávez-Crocker $P$, Obreque-Contreras J (2011) Bioremediation of aquaculture wastes. Curr Opin Biotech 21: 313-317.

37. Buřič M, Bláhovec J, Kouřil J (2014) The use of constructed wetland for water treatment in recirculating hatchery for salmonids. Edice Metodik (Technology series), FFPW USB Vodňany, Czech Republic.

38. Tello A, Comer RA, Telfer TC (2010) How do land-based salmonid farms affect stream ecology? Environ Pollut 158: 1147-1158.

39. Schneider O, Sereti V, Eding EH, Vereth JAJ (2005) Analysis of nutrient flows in integrated intensive aquaculture systems. Aquacult Eng 32: 379-401. 